\title{
Agnieszka STĘPIŃSKA
}

Uniwersytet im. Adama Mickiewicza, Poznań

\section{Wizerunek polityka lokalnego i rola środków masowego przekazu w jego ksztaltowaniu}

\section{Pojęcie wizerunku} Wizerunek (image) to „subiektywne wyobrażenie o jakiejś sprawie, ry zależy w dużej mierze od ,życzeń, tęsknot, obaw, doświadczeń oraz nastawień" osoby, która go formułuje. Konstruowanie tego typu obrazów stanowi odpowiedź na właściwość ludzkiego umysłu, jaką jest istnienie granicy możliwości percepcyjnych. Psycholodzy wskazują, iż w sytuacji, gdy „liczba wiadomości, z jakimi styka się człowiek jest ogromna, konieczne staje się jej zredukowanie do takiej wielkości, nad jaką można zapanować"2. Służą temu w szczególności takie zabiegi jak selekcja odbieranych przekazów oraz tworzenie schematów, czyli tzw. struktur poznawczych. Schematy te pozwalają organizować posiadaną i nabywaną wiedzę, zmniejszyć liczbę koniecznych do uwzględnienia danych i interpretować informacje wieloznaczne ${ }^{3}$.

Kształtowanie swojego własnego wizerunku (obrazu w oczach innych) stanowi wyraz uświadomionej autoprezentacji. Naturalną potrzebą człowieka - jako „istoty społecznej”"4, jest zaprezentowanie się innym z jak najlepszej strony lub też w sposób, który w danej sytuacji wydaje się być najkorzystniejszy z punktu widzenia danej jednostki. Zwrócił na to uwage już E. Goffman, który pisał, że uczestnicy relacji międzyludzkich mają skłonność do idealizacji, czyli ,podsuwania ich obserwatorom swych wyidealizowanych na różne sposoby obrazów"s. Autoprezentacja służy

1 K. Huber, Image czyli jak być gwiazda na rynku, Warszawa 1994, s. 25.

2 E. Aronson, T. Wilson, R. Akert, Psychologia społeczna: serce i umyst, Poznań 1997, s. 128-147. Por. Z. J. Pietraś, Decydowanie polityczne, Warszawa-Kraków 1998, s. 419.

3 Z. J. Pietraś, op. cit., s. 419-420.

4 E. Aronson, Człowiek istota społeczna, Warszawa 1995.

5 Cyt. E. Goffman, Człowiek w teatrze życia codziennego, Warszawa 2001, s. 65. 
w szczególności oddziaływaniu interpersonalnemu, budowie i podtrzymywaniu poczucia własnej wartości oraz regulowaniu emocji ${ }^{6}$. Potrzeba kontrolowania wywieranego wrażenia wzrasta w sytuacji gdy: 1) jednostka jest przekonana, iż istnieje związek między wywieranym przez nią wrażeniem a celami, które zamierza osiagnąć; 2) cele te są dla niej ważne; $3)$ istnieje rozbieżność między tym wizerunkiem, który chciałaby zaprezentować, a tym, który w jej przekonaniu odbierają inni ${ }^{7}$. Motywacja do kontrolowania tego staje się więc bardzo silna, zwłaszcza w sytuacjach o charakterze publicznym oraz w których jednostka zależy od innych - a zatem w okolicznościach, z którymi mają do czynienia uczestnicy rywalizacji wyborczej ${ }^{8}$, także na poziomie lokalnym. Zgodnie z tym ujęciem, wizerunek jest swoistym przekazem (komunikatem) na temat samego siebie, który jednostka formułuje w sytuacji kontaktu z innymi.

Na przekaz ten składają się rzeczywiste właściwości jednostki: cechy społeczno - demograficzne (wiek, płeć, status rodzinny, miejsce pochodzenia, miejsce zamieszkania, wykształcenie, zawód), motywy, ambicja i temperament oraz zachowania werbalne i niewerbalne, a także typ osobowości politycznej. Istotnym elementem są również uprzednie relacje oraz najbliższe otoczenie jednostki (rodzina, współpracownicy) i jego charakterystyka. Wizerunek budowany jest z tych cech zwykle w oparciu o tzw. wyłączającą strategię autoprezentacji, polegającą na podkreślaniu jednych, a ukrywaniu innych cech. Decyzja o tym, jakie modyfikacje rzeczywistego obrazu danej osoby zostaną zastosowane zależy przede wszystkim, jak już wspomniano, od funkcjonujących w danym systemie i społeczeństwie norm związanych z pełnieniem określonej roli ${ }^{9}$.

\section{Oczekiwania społeczne}

W opinii Polaków dobra władza charakteryzuje się trzema podstawowymi przymiotami: sprawiedliwością, siłą i fachowością. Taki sposób

6 M. Leary, Wywieranie wrażenia na innych. O sztuce autoprezentacji, Gdańsk 1999 , s. $54-58$.

7 Ibidem, s. 67.

8 Szerzej o tym: M. Leary, op. cit., s. 62-65.

9 Jak pisał E. Goffman, „występ ucieleśnia i odzwierciedla wartości oficjalne danego społeczeństwa [...]. Jeśli jednostka w trakcie występu ma zamiar wyrazić idealne wzorce, musi wówczas ukryć lub powstrzymać się przed działaniami z nimi niezgodnymi”. Cyt. E. Goffman, op. cit., s. 71. 
oceny władzy odpowiada wzorcom zachodnim, niemniej specyfika polska ujawnia się w sposobie definiowania powyższych pojęć. I tak, z władzą sprawiedliwą kojarzą się Polakom takie cechy jak: równość wobec prawa, równość szans, szczerość, dotrzymywanie składanych obietnic, wolność od korupcji oraz dzielenie według określonych zasad. Z kolei siła władzy wiąże się ze zdolnością do podejmowania niepopularnych decyzji, nieuleganiem wpływom, kompetencją oraz legitymizacją w postaci wyboru przez większość. Pojęcie fachowości zawiera zaś w sobie: odpowiednie przygotowanie, doświadczenie, talent, zdolności organizatorskie oraz zaangażowanie ${ }^{10}$.

Źródłem wiedzy o oczekiwaniach społecznych wobec potencjalnych kandydatów i o tym, jakie cechy polityków lokalnych cenione są najwyżej mogą być wyniki badań prowadzonych nad zachowaniami wyborców lokalnych (m.in. sondaży opinii publicznej). Z badań przeprowadzonych przez A. Michalaka z Uniwersytetu Szczecińskiego ${ }^{11}$ wynika, że tym, co najbardziej przekonuje wyborców lokalnych do oddania głosu na danego kandydata jest dotychczasowa działalność danej osoby na rzecz społeczności lokalnej. Drugim ważnym czynnikiem skłaniającym do wyborczego poparcia jest fakt osobistej znajomości z kandydatem, zaś trzecim - opinia osób, które mają duży autorytet w środowisku. Natomiast na czwartym miejscu wymieniane są działania podejmowane w czasie kampanii wyborczej.

Wymienione czynniki istotnie determinują zbiór cech, których posiadanie przez kandydata uznawane jest za pożądane z punktu widzenia jego potencjalnych wyborców. I tak, niezwykle ważny jest czas, od jakiego kandydat zamieszkuje dany teren. W przypadku kandydatów lokalnych czas stanowi bowiem ,funkcję ilości i różnorodności kontaktów interpersonalnych między taką osobą a przedstawicielami społeczności lokalnej" ${ }^{\prime 2}$. Warto przy tym pamiętać, iż jest sprawą indywidualną, ile czasu potrzeba na poznanie problemów społeczności lokalnej lub przynajmniej

10 Za: M. Ziółkowski, B. Pawłowska, R. Drozdowski, Jednostka wobec władzy, Poznań 1994, s. 147. Wymienione wyżej cechy korespondują w dużej mierze ze zbiorem cech preferowanych u kandydatów na urząd prezydenta w USA: kompetencja, atrakcyjnością, moralnością oraz opanowaniem i stanowczością. Zob. M. Leary, op. cit., s. 97-99.

11 A. Michalak, Lokalni wyborcy samorzadowi. Socjologiczne studium politycznych reprezentacji zachowań wyborczych, Szczecin 2001.

12 Ibidem, s. 101. 
sprawienia wrażenia, że się je zna. Kwestia czasu zamieszkania na danym terenie wiąże się więc $\mathrm{z}$ jednej strony $\mathrm{z}$ identyfikacją kandydata $\mathrm{z}$ danym terenem i społecznością, $\mathrm{z}$ drugiej zaś $\mathrm{z}$ identyfikacją społeczności lokalnej z kandydatem i jego popularnością wśród wyborców.

Element długości czasu zamieszkania danego kandydata na określonym terenie (np. w gminie) nierzadko połączony jest z kolejnym - tradycjami zamieszkiwania danych ziem przez rodzinę kandydata („,korzenie rodzinne"). Należy przy tym zauważyć różnice w oczekiwaniach stawianych w tym zakresie kandydatom wynikające z odmiennej historii poszczególnych ziem polskich. O ile bowiem w Wielkopolsce, Małopolsce czy na południu naszego kraju można mówić o wielopokoleniowej tradycji zamieszkiwania, o tyle w przypadku Ziem Odzyskanych tradycje te oznaczają często maksymalnie trzy pokolenia ${ }^{13}$. Stąd też na Pomorzu Zachodnim czy też na Dolnym Śląsku wspomniany element biografii kandydata jest mniej istotny dla jego potencjalnych wyborców.

Ponadto, problem wielopokoleniowego zasiedzenia stanowi znaczącą wartość głównie w społecznościach wiejskich, w których liczba ludności utrzymuje się na stałym poziomie, zaś skład rodzinny pozostaje zasadniczo niezmienny przez dłuższy czas. Nie jest jednak tak, iż element ten nie pełni żadnej roli w przypadku polityków lokalnych w gminach miejskich - choć znaczenie wspomnianego elementu jest mniejsze, to i tu zwraca się uwagę na doświadczenia rodzinne kandydata w sferze politycznej, społecznej czy kulturalnej ${ }^{14}$. Jako przykład można w tym miejscu przytoczyć Jarosława Kalinowskiego - byłego prezesa Polskiego Stronnictwa Ludowego, który nawet $\mathrm{w}$ trakcie kampanii prezydenckiej podkreślał fakt, iż swój wybór na wójta wsi Jackowo na Kurpiach zawdzięcza zaufaniu, jakim mieszkańcy tej wsi darzyli jego rodzinę (J. Kalinowski był najmłodszym jak dotąd wójtem w Polsce).

Kolejnym ważnym elementem biografii przyszłego polityka lokalnego jest jego zawód, a dokładniej prestiż lub jego brak związany z wykonywaniem danego zawodu. Przedstawiciele społeczności lokalnej - jak wykazał w swoich badaniach A. Michalak - istotnie różnią się oceną poszczególnych zawodów od społeczności krajów zachodnich z ukształtowaną demokracją, także na szczeblu lokalnym. I tak, największy prestiż charakteryzuje w Polsce zawód lekarza i nauczyciela. Stosunkowo nisko

13 Ibidem, s. 107-108.

14 Ibidem, s. 106-107. 
są natomiast oceniane takie zawody jak: dyrektor banku, prawnik czy ekonomista ${ }^{15}$. Polscy wyborcy lokalni nie uznają zatem za prestiżowe tych zawodów, które wiążą się z, wydawałoby się, ważnym cechami polityka lokalnego, takim jak: decyzyjność, samodzielność, umiejętność zbierania i przetwarzania danych, czy wreszcie posiadanie wiedzy z zakresu prawa czy finansów.

Wydaje się, iż wynika to z faktu, że w gminach wiejskich osób wykonujących takie zawody jest wciąż niewiele - stąd brak doświadczeń w posiadaniu przez te społeczności takich reprezentantów i być może niechęć lub obawa do zagłosowania na nich. Po drugie, wspomniane zawody, jak również fakt pełnienia funkcji kierowniczych, mogą tworzyć dystans społeczny pomiędzy kandydatem i wyborcami. Większy prestiż przypisywany jest zawodom gorzej opłacanym, ale znacznie bardziej znajomym i - tradycyjnie łączonym ze służbą społeczną.

Następnym elementem istotnym dla wyborców lokalnych jest majatek posiadany przez kandydata. Fakt posiadania dużego majątku ma znaczenie szczególnie dla mieszkańców gmin wiejskich, w tym zwłaszcza najmłodszych wyborców (grupa wiekowa: 18-24). W społecznościach tych waga wspomnianego elementu maleje wraz ze wzrostem wysokości dochodów osiaganych przez potencjalnego wyborcę ${ }^{16}$. W świetle powyższych danych zrozumiały staje się fakt, dlaczego kandydaci z ugrupowań kierujących swą ofertę wyborczą do ubogich mieszkańców wsi, eksponują posiadany majątek (np. „Samoobrona”) - zewnętrzne przejawy korzystnej sytuacji finansowej kandydata przez część wyborców traktowana jest bowiem jako dowód na jego skuteczność i zaradność.

W przeciwieństwie do wyborów parlamentarnych i prezydenckich, mniejsze znaczenie dla wyborców ma natomiast przynależność partyjna kandydatów ubiegających się o funkcje lokalne. Znaczenie upartyjnienia kandydatów w wyborach rośnie wraz ze wzrostem liczby mieszkańców gminy, ich wykształcenia oraz dochodów.

Spośród cech osobowościowych potencjalnych polityków lokalnych wyborcy najwyżej cenią umiejętności organizatorskie, inicjatywę oraz umiejętność kierowania większymi grupami (społecznością lokalną), czyli posiadanie predyspozycji do roli lidera ${ }^{17}$. Tego typu deklaracje są sprzeczne z wcześniej przytoczonymi deklaracjami dotyczącymi prestiżu

15 Ibidem.

16 A. Michalak, op. cit., s. 108-109.

17 Ibidem, s. 113-114. 
zawodów i poziomu zaufania do ludzi je wykonujących. Wskazuje to na fakt, iż z niektórymi zawodami związane są negatywne stereotypy, zaś te same cechy charakteryzujące ludzi wykonujących inne zawody są nie tylko akceptowane, ale wręcz postrzegane jako pożądane u lokalnych polityków.

\section{Kreowanie wizerunku}

P. Braud w pracy Rozkosze demokracji ${ }^{18}$, stworzył interesujący model zastosowania wyłączającej strategii autoprezentacji do budowy wizerunku składającego się z cech społeczno-demograficznych. W swoim modelu Braud wskazał te cechy, które podczas kształtowania wizerunku należy jedynie uwydatnić (pozytywnie oceniane cechy, naturalnie wynikające z czynników demograficzno-społecznych) oraz tzw. ,punkty do podkreślenia", którymi są te elementy, które ze względu na ich negatywną społeczną lub kulturową ocenę, powinny być ukryte i które w sytuacji, gdy ukryć ich nie można, muszą zostać zneutralizowane. Koncepcję P. Brauda wykorzystać można do opracowania zestawienia uwzględniającego elementy, które mają istotne znaczenie w przypadku polityków lokalnych w Polsce.

Wyłączająca strategia autoprezentacyjna może być również zastosowana w odniesieniu do cech osobistych. Wówczas, cechy które podlegają podkreślaniu w procesie budowy wizerunku podzielić można na kilka kategorii. Do pierwszej należą ,zdolności przywódcze, na które składają się: umiejętność sprawowania silnego przywództwa, uzyskiwania szacunku i zdolność inspirowania podwładnych”. Drugą kategorię tworzy „kompetencja, czyli umiejętność ciężkiej pracy, inteligencja i wiedza”, trzecią zaś „integralność wewnętrzna kandydata, wynikająca z jego uczciwości, przyzwoitości, moralności oraz zdolności dawania dobrego przykładu”. Czwartą kategorię stanowi natomiast empatia, czyli „umiejętność dbania o obywateli, miłe usposobienie oraz zdolność do wyrażania współczucia"19.

Zgodnie z tym, co zostało wspomniane wcześniej, na wizerunek osobisty składają się również zachowania werbalne i niewerbalne. Do pierwszych należy język (jako przejaw kodu, czyli sposobu postrzegania świata i formułowania myśli), stanowiący wypadkową wykształcenia, miejsca

18 P. Braud, Rozkosze demokracji, Warszawa 1995.

19 P. Pierce, Political Sophistication and the Use of Candidate Evaluation, „Political Psychology" 1993, nr 1, s. 24-25. Cyt. za: Z. J. Pietraś, op. cit., s. 425. 
Tabela 1

Elementy biograficzne wizerunku polityka lokalnego - cechy do uwydatnienia i punkty do podkreślenia (specyfika polska)

\begin{tabular}{|c|c|c|c|}
\hline $\begin{array}{c}\text { Tożsamość } \\
\text { rzeczywista }\end{array}$ & $\begin{array}{c}\text { Cechy do } \\
\text { uwydatnienia }\end{array}$ & \multicolumn{2}{|c|}{ Punkty do podkreślenia } \\
\hline \multirow[t]{5}{*}{ Zawód } & $\begin{array}{l}\text { Kadra kierow- } \\
\text { nicza (sektor } \\
\text { publiczny) }\end{array}$ & $\begin{array}{l}\text { Znajomość powierzonych spraw, } \\
\text { oddanie dla spraw natury ogól- } \\
\text { nej }\end{array}$ & $\begin{array}{l}\text { Dystans do rutynowych działań } \\
\text { biurokratycznych, samodziel- } \\
\text { ność, świeżość pomysłów i roz- } \\
\text { wiązań }\end{array}$ \\
\hline & $\begin{array}{l}\text { Kadra kierow- } \\
\text { nicza (sektor } \\
\text { prywatny) }\end{array}$ & $\begin{array}{l}\text { Skuteczność, kompetencja, zna- } \\
\text { jomość zagadnień gospodar- } \\
\text { czych }\end{array}$ & $\begin{array}{l}\text { Interesowanie się sprawami lu- } \\
\text { dzi (kwestie społeczne) }\end{array}$ \\
\hline & Nauczyciel & $\begin{array}{l}\text { Umiejętność analizy, blisko } \\
\text { spraw młodzieży }\end{array}$ & $\begin{array}{l}\text { Odrzucanie dogmatów, upodo- } \\
\text { banie do rzeczy konkretnych }\end{array}$ \\
\hline & Wolny zawód & $\begin{array}{l}\text { Niezależność, odpowiedzialność, } \\
\text { oddanie ludziom, umiejętność } \\
\text { publicznego występowania, zdol- } \\
\text { ności organizatorskie }\end{array}$ & $\begin{array}{l}\text { Konieczność szerszego spoj- } \\
\text { rzenia na politykę, większego } \\
\text { zaangażowania w sprawy pu- } \\
\text { bliczne }\end{array}$ \\
\hline & $\begin{array}{l}\text { Środowisko } \\
\text { robotnicze }\end{array}$ & $\begin{array}{l}\text { Identyfikowanie się z najuboż- } \\
\text { szymi, bliskość spraw ludzi, } \\
\text { zdrowy rozsądek }\end{array}$ & $\begin{array}{l}\text { Zdolność prowadzenia spraw } \\
\text { złożonych, nabywanie nowych } \\
\text { umiejętności i kompetencji }\end{array}$ \\
\hline \multirow{2}{*}{$\begin{array}{l}\text { Miejsce po- } \\
\text { chodzenia } \\
\text { i zamieszkania }\end{array}$} & Miejscowy & ,Jestem jednym z was” & $\begin{array}{l}\text { Dobre stosunki z ludźmi } \\
\text { z zewnątrz, szerokie kontakty }\end{array}$ \\
\hline & Z zewnątrz & Dyskrecja lub ,jestem spoza” & $\begin{array}{l}\text { Szczególna miłość do „małej } \\
\text { ojczyzny” }\end{array}$ \\
\hline \multirow[t]{2}{*}{$\begin{array}{l}\text { Czas zamiesz- } \\
\text { kania na da- } \\
\text { nym obszarze }\end{array}$} & Długi & $\begin{array}{l}\text { Znajomość problemów lokal- } \\
\text { nych }\end{array}$ & $\begin{array}{l}\text { Znajomość problemów regional- } \\
\text { nych, ogólnokrajowych i mię- } \\
\text { dzynarodowych }\end{array}$ \\
\hline & Krótki & $\begin{array}{l}\text { Uzasadnienie wyboru danego } \\
\text { miejsca }\end{array}$ & $\begin{array}{l}\text { Łatwość rozpoznawania i ana- } \\
\text { lizowania nowych problemów }\end{array}$ \\
\hline \multirow{2}{*}{$\begin{array}{l}\text { Rodzinne tra- } \\
\text { dycje aktyw- } \\
\text { ności } \\
\text { publicznej }\end{array}$} & Istnieją & $\begin{array}{l}\text { Wychowanie w duchu aktyw- } \\
\text { ności społecznej }\end{array}$ & $\begin{array}{l}\text { Posiadanie wzorców działania } \\
\text { oraz wsparcia ze strony do- } \\
\text { świadczonych osób }\end{array}$ \\
\hline & Brak & Poczucie misji, wola działania & $\begin{array}{l}\text { Entuzjazm, nowatorskie po- } \\
\text { mysły }\end{array}$ \\
\hline \multirow[t]{2}{*}{ Majątek } & Duży & $\begin{array}{l}\text { Sprawność działania, zarad- } \\
\text { ność, skuteczność }\end{array}$ & $\begin{array}{l}\text { Zachowanie prostego trybu ży- } \\
\text { cia }\end{array}$ \\
\hline & Niewielki & Prostota, bezinteresowność & $\begin{array}{l}\text { Znajomość problemów ludzi, } \\
\text { satysfakcja z życia, wartości } \\
\text { pozamaterialne }\end{array}$ \\
\hline \multirow[t]{2}{*}{$\begin{array}{l}\text { Wykształce- } \\
\text { nie }\end{array}$} & $\begin{array}{l}\text { Podstawowe, } \\
\text { zawodowe, } \\
\text { średnie } \\
\end{array}$ & $\begin{array}{l}\text { Znajomość ciężkiej pracy fi- } \\
\text { zycznej, problemów zwykłych } \\
\text { ludzi, zdrowy rozsądek }\end{array}$ & $\begin{array}{l}\text { Ciagłe podnoszenie swoich kwa- } \\
\text { lifikacji, praca nad sobą, podkre- } \\
\text { ślanie wartości wykształcenia }\end{array}$ \\
\hline & Wyższe & $\begin{array}{l}\text { Szeroka wiedza, zrozumienie dla } \\
\text { złożonych problemów, umiejęt- } \\
\text { ność analizowania i prognozowa- } \\
\text { nia, znajomość języków obcych }\end{array}$ & $\begin{array}{l}\text { Zainteresowanie ludźmi, ko- } \\
\text { munikatywność, brak dystansu }\end{array}$ \\
\hline
\end{tabular}

Źródło: Opracowanie własne. 
pochodzenia (zamieszkania), środowiska, z jakiego się wywodzi dana osoba oraz jej temperamentu ${ }^{20}$. Kontrolowanie wywieranego wrażenia poprzez świadome kreowanie tego elementu pozwala wyraźnie wskazać odbiorcę, do którego kieruje swój przekaz kandydat. Do zachowań niewerbalnych zaliczyć można natomiast takie cechy jak: „wyraz twarzy, ton głosu, akcent, język ciała, włosy, zęby, tuszę, wzrost, zdrowie, sprawność, energię życiowa, postawę, ubiór, biżuterię, typ samochodu, styl jedzenia i picia itp." ${ }^{21}$ Wygląd fizyczny, poza ogólnym wrażeniem estetycznym, pełni jeszcze inną bardzo istotną rolę: pewne cechy, jak wzrost czy też tusza odbierane sa jako przejawy określonych cech charakteru i mogą być interpretowane na korzyść lub niekorzyść kandydatów. Wygląd może więc, wraz z fachowością, kontrować siłę, autorytet i inne politycznie pożądane atrybuty ${ }^{22}$.

Elementem wizerunku jest także typ osobowości politycznej, który reprezentuje dany kandydat (w przekazach ujawnia go zwykle wymiar wartości). Osobowość polityczna stanowi tę część osobowości społecznej jednostki, która przesądza o tym ,z jakimi interesami i grupami społecznymi identyfikuje się dana osoba, w czyim interesie działa, jakie ma cele pozaindywidualne, jak je ze sobą godzi, jakie podejmuje działania, wobec kogo i w czyim imieniu"23. Zwykle kandydaci deklarują, kierowanie się

20 Jak pisze J. Fras, „każda osoba publiczna istnieje w znacznym stopniu poprzez swój język, poprzez to jak i co mówi". Cyt. J. Fras, Kształtowanie się nowego języka polityki po 1989 r. - udziat Lecha Watęsy, w: Z badań nad przemianami politycznymi w Polsce po '98, pod. red. S. Dąbrowskiego, B. Rogowskiej, Wrocław 1998, s. 52. Tak rozumiany język należy odróżnić od retoryki, jaką posługuje się dany podmiot wyborczy przy formułowaniu przekazów programowych. Retoryka stanowić będzie przedmiot rozważań zawartych w kolejnym rozdziale niniejszej pracy. Przytoczone wyżej pojęcie kodu stanowi element popularnej teorii B. Bernsteina (teoria kodu ograniczonego i rozwiniętego). Zob. B. Bernstein, Socjolingwistyczne ujęcie procesu socjalizacji: uwagi dotyczqce podatności na oddzialywanie szkoły, w: Badania nad rozwojem języka dziecka, Warszawa 1980.

${ }^{21}$ Cyt. za: Z. J. Pietraś, op. cit., s. 427.

22 B. Mc Nair, Wprowadzenie do komunikowania politycznego, Poznań 1997, s. 142. Por. N. de Barbaro, O szufladkach w głowach, drogach na skróty i szukajacym pijaku, „Charaktery” 1998, nr 10, s. 21, a także: W. Domachowski, Komunikacja niewerbalna, w: W. Domachowski, S. Kowalik, J. Miluska, $Z$ zagadnień psychologii społecznej, Warszawa 1984 oraz W. Głodkowski, Bez słowa. Komunikacyjne funkcje zachowań niewerbalnych, Warszawa 1999; M. Argyle, Psychologia stosunków międzyludzkich, Warszawa 1995.

${ }^{23}$ Cyt. za: Z.J. Pietraś, op. cit., s. 325. Por. też: Korporowicz, Osobowość i komunikacja $w$ spoleczeństwie transformacji, Warszawa 1996, s. 133. 
motywami pozaosobistymi (jednostka zostaje uczestnikiem rynku wyborczego, gdyż istnieje „wielka sprawa, której chce służyć” ${ }^{24}$. Tymczasem rzeczywiste motywacje udziału w wyborach mogą być różne: osoba angażująca się w politykę może liczyć bądź na korzyści materialne płynące ze sprawowania funkcji publicznej, bądź też korzyści niematerialne, symbolicznych, takie jak: prestiż, autorytet, popularność, awans w hierarchii zabierania głosu ${ }^{25}$. Tym, co motywuje do udziału w polityce może być także np. przyjemność z posiadania władzy, a zatem możliwość decydowania, zarządzania innymi, kierowania karierami ludzi i rozwikłania problemów.

Wspomnianą wyżej wyłączającą strategię autoprezentacyjną realizować można poprzez zastosowanie szeregu różnych taktyk. Pierwszą z nich jest opisywanie siebie w taki sposób, aby wywrzeć na innych pożądane wrażenie; drugą: wyrażenie postaw sugerujących, że dana jednostka ma takie, a nie inne cechy; trzecią taktyką są publiczne atrybucje, polegające na wyjaśnianiu własnego zachowania w sposób zgodny z określonym wizerunkiem społecznym (publicznym). Do często stosowanych taktyk należy także pamięciowa manipulacja, czyli rzeczywiste lub udawane zapamiętywanie bądź zapominanie o pewnych kwestiach w celach autoprezentacyjnych. Wspomnieć tu należy jeszcze o takich metodach jak: zachowania niewerbalne podejmowane świadomie, kontakty społeczne (publiczne manifestowanie związków z pewnymi osobami i odcinanie się od innych), a także konformizm i uleganie (czyli zachowanie się zgodnie ze społecznymi normami albo z preferencjami innych ludzi) oraz dekoracje, rekwizyty i oświetlenie, czyli wykorzystanie elementów otoczenia (środowiska) do celów autoprezentacyjnych ${ }^{26}$.

Podstawową zasadą tworzenia wizerunku jest zgodność, czyli dopasowanie sposobu autoprezentacji do, z jednej strony cech rzeczywistych (wizerunek nie może stanowić ich zaprzeczenia), z drugiej zaś do oczeki-

24 Ibidem, s. 178-182. Szerzej o tym: E. Karpowicz, Motywy kandydowania do Sejmu, w: Świat elity politycznej, red. W. Wesołowski, I. Panków, Warszawa 1995, 275-295.

25 P. Braud, op. cit., s. 155-158.

26 M. Leary, op. cit., s. 50-52. Ujęcie takie bliskie jest koncepcji występu, którą sformułował E. Goffman. W myśl tej koncepcji, częścią występu jest tzw. fasada osobista - te środki wyrazu, które najmocniej związane są z samym wykonawcą (przemieszczają się wraz z nim). Należą do nich takie cechy jak: płeć, wiek, powierzchowność (postura, wygląd) oraz styl bycia, a także np. insygnia związane z zajmowaną pozycją lub pełnionym urzędem. Zob. E. Goffman, op. cit., s. 53-54. 
wań innych uczestników interakcji i własnych celów jednostki. Stąd też wizerunek musi mieć charakter komplementarny i musi być kształtowany konsekwentnie, z drugiej zaś strony konieczna jest elastyczność autoprezentacji i umiejętność szybkiego reagowania na sytuacje kryzysowe (tzw. tarapaty autoprezentacyjne), których źródłem może być bądź sam kandydat i jego najbliższe otoczenie (publiczne uchybienie normom, przypadkowe wyrządzenie szkody) lub też rywale w konkurencji wyborczej (prowokacje lub ujawnienie niekorzystnych informacji). Istotnym źródłem ograniczeń w kreowaniu wizerunku osoby publicznej jest także problem zróżnicowania publiczności - w przypadku wyborów prezydenckich, których celem działań promocyjnych jest uzyskanie jak najszerszego poparcia, konieczne jest uwypuklenie cech pozytywnie ocenianych przez stosunkowo duże grupy. Podstawowa trudność procesu kreowania wizerunku polega zatem na takim dostosowaniu autoprezentacji, by nie została zatracona naturalność - zbyt usilne kontrolowanie wywieranego wrażenia sprawia wrażenie sztuczności i tym samym podważa wiarygodność jednostki (dylemat autoprezentacyjny).

\section{Rola środków masowego przekazu}

Jak już wspomniano, wizerunek stanowi swoisty przekaz, który rozpowszechniany jest w bliższym i dalszym otoczeniu danej osoby. W przypadku polityków lokalnych - jak zresztą wszystkich osób publicznych głównymi odbiorcami tego przekazu są dwie grupy: wyborcy (społeczeństwo) oraz media (dziennikarze, redaktorzy). Przekaz ten docierać może do wspominanych odbiorców za pośrednictwem różnych kanałów. Może być to kontakt bezpośredni (spotkanie, rozmowa, podanie ręki) lub też pośredni w postaci ulotek, plakatów oraz materiałów rozpowszechnianych poprzez środki masowego przekazu. Innymi słowy, kształtowanie wizerunku jest procesem komunikowania o charakterze interpersonalnym i masowym.

Specyfika samorządowej kampanii wyborczej, w szczególności tej prowadzonej w gminach wiejskich, polega na tym, iż przede wszystkim wykorzystywane są techniki bezpośredniej komunikacji wyborczej. Do najpopularniejszych form prezentacji i promocji kandydatów należą: zebrania, odwiedziny wyborców w ich domach, zabawy, festyny, agitacja w kościołach oraz spotkania organizowane w gospodach czy w remizach strażackich. Plakaty wyborcze, ulotki oraz ogłoszenia radiowe i prasowe 
czy też audycje wyborcze w telewizji mają w tym przypadku znaczenie uzupełniające. Natomiast w gminach miejskich - większych i bardziej licznych, komunikacja pośrednia odgrywa bardziej istotną rolę podczas kampanii wyborczych.

Pytanie o rolę mediów w procesie kształtowania wizerunku osoby publicznej (tu: polityka lokalnego) dotyczy de facto ich roli w systemie politycznym i społecznym. W systemach demokratycznych, zakładających istnienie wolnych mediów, środki przekazu mogą pełnić trzy podstawowe funkcje: kanału przekazów, samodzielnego uczestnika komunikowania nadawcy przekazów oraz tzw. gatekeeperów, dokonujących selekcji informacji oraz stymulujących proces komunikowania.

W pierwszym z podanych przypadków media traktowane są jako element nieaktywny, którego zadaniem jest rozpowszechnianie przekazów przygotowanych poza jego strukturami. Z sytuacją taką mamy do czynienia na przykład wówczas, gdy media rozpowszechniają audycje wyborcze poszczególnych kandydatów (tu: biorących udział w wyborach samorządowych), w określonych ustawowo ramach czasowych i na zdefiniowanych przez prawo wyborcze zasadach. Podstawową zaletą tej formy kreowania i rozpowszechniania wizerunku jest fakt, iż przekaz przygotowany przez nadawcę (polityka lokalnego i jego najbliższe otoczenie) w niezmienionej postaci dociera do odbiorców docelowych, czyli potencjalnych wyborców. Tym samym podkreślone i uwydatnione mogą być te cechy kandydata, które były wskazywane jako pożądane u polityka lokalnego.

Główną wadą tego typu przekazów jest natomiast ich ograniczona skuteczność, wynikającą z dwóch powodów. Po pierwsze, odbiorcy reklam (audycji wyborczych) zdają sobie sprawę z próby wywarcia wpływu na ich poglądy, postawy i zachowania. Po drugie natomiast, jak wskazuja wyniki badań, oglądalność tego typu przekazów (bloków audycji wyborczych) jest zwykle niewielka (sięga ok. 5\%). Niemniej jednak, stwierdzić można, iż potencjalnie tego typu przekazy mogą pełnić dwie podstawowe funkcje: informowanie wyborców o fakcie kandydowania danej osoby (upowszechnienie nazwiska, twarzy oraz tego, iż polityk bierze udział w rywalizacji wyborczej) oraz przekonywanie wyborców o posiadaniu przez polityka predyspozycji do zajmowania określonych funkcji (wskazywanie na cechy, dotychczasowe osiagnnięcia, doświadczenia). Jednocześnie, w przekazach takich odwołać się można do czynników zwiększających szansę na zdobycie poparcia wyborczego (np. poprzez udział w audycjach wyborczych osób cieszących się autorytetem w danej społeczności, wypowiedzi wspierające kandydaturę, wspólne zdjęcia itp.). 
Nie sposób natomiast przecenić znaczenia mediów (zarówno ogólnopolskich, jak i lokalnych) jako źródła informacji o wydarzeniach ze świata, kraju i regionu. Także w okresie kampanii wyborczej Polacy czerpią wiedzę o poszczególnych wydarzeniach właśnie z mediów, w tym głównie $\mathrm{z}$ telewizji $\mathrm{i}$ - o wydarzeniach $\mathrm{z}$ najbliższego sobie otoczenia - z prasy lokalnej i lokalnych rozgłośni radiowych. Media podejmują się wówczas bowiem kilku zadań: prezentowania wydarzeń związanych z poszczególnymi etapami okresu przedwyborczego (m.in. tworzeniem list wyborczych i ich rejestracja), ukazywania sylwetek kandydatów oraz relacjonowanie działalności promocyjnej podejmowanej przez poszczególnych uczestników rywalizacji wyborczej. Tym samym, podczas kampanii wyborczej media te zyskują szczególną moc - mogą istotnie wpływać na wizerunki kształtowane przez kandydatów. Biorąc pod uwagę oczekiwania społeczne i czynniki wpływające na decyzje wyborcze, dostrzec można kilka obszarów potencjalnego oddziaływania mediów na postawy i zachowania wyborców.

I tak, media lokalne prezentując kandydatów wymieniają, opisują i akcentują cechy każdego z nich, przy czym nie zawsze są to te same cechy, które ukazywali i podkreślali w swoich audycjach wyborczych kandydaci. Dziennikarze, poprzez swoje przekazy, mogą zatem wzmacniać lub burzyć wizerunek kształtowany przez polityków. Niemniej jednak, poświęcając uwage poszczególnym kandydatom (przeprowadzając wywiady, przygotowując reportaże czy też krótkie depesze, których tematem jest osoba lub działalność danego polityka lokalnego) przyczyniają się do podniesienia poziomu jego rozpoznawalności czy nawet popularności.

Ponadto, zarówno podczas kampanii wyborczej, jak i pomiędzy wyborami, media relacjonują podejmowane decyzje, inicjatywy poszczególnych osób oraz definiują problemy dotąd nierozstrzygnięte, wskazując jednocześnie, kto jest odpowiedzialny za podjęcie działania w danej sprawie. Tym samym media dostarczają dowodów na aktywność lub jej brak w przypadku poszczególnych osób i w konsekwencji, potwierdzają lub zaprzeczają informacjom podawanym przez samych kandydatów. Dodatkowo, media (w tym także lokalne) stanowić mogą forum wymiany poglądów kandydatów (dyskusje z udziałem polityków) oraz wymiany zdań pomiędzy wyborcami (reprezentantami danej społeczności lokalnej) a politykami (drukowanie listów czytelników, ich wypowiedzi czy też pytań).

Z omawianą działalnością mediów wiąże się problem ich niezależności i obiektywności. Jak pisze R. Kowalczyk, ,prasa lokalna nie jest do- 
skonałym narzędziem komunikowania społecznego, choćby z powodu często występującej tendencyjności w selekcji materiałów [...], czy zaangażowania politycznego jej wydawców, dziennikarzy oraz ich uwikłań w personalnym i politycznym układzie lokalnym" ${ }^{27}$. Jednym z zabiegów dokonywanych przez media lokalne jest personalizacja wydarzeń lokalnych - każde z nich ma „swojego autora lub negatywnego bohatera" 28 . Tym samym, relacjonowanie życia społeczności lokalnej często wiąże się z prezentacją osób zaangażowanych $\mathrm{w}$ dane działania czy wydarzenia, co z kolei stwarza możliwości oddziaływania na wizerunki poszczególnych polityków lokalnych.

\section{Summary}

The Author of the paper discusses the notion of the image, presents the expectations of Poles concerning politicians (in particular politicians at a local level), and pays particular attention to the importance of the diversified history of different regions in Poland. The paper also addresses the problem of how an image is created emphasizing those elements that are significant from the perspective of a local politician. Finally, the Author refers to the significance of the mass media and direct electioneering during a campaign at a local level.

27 R. Kowalczyk, Rola prasy lokalnej w ksztaltowaniu systemu politycznego (wybrane zagadnienia), w: W kręgu mediów i polityki, por red. D. Piontek, Poznań 2003, s. 104 .

28 Ibidem. 